\title{
Verbal images of evil and (in)humanity during and after the Holocaust
}

\author{
JenNifer L. Geddes
}

\begin{abstract}
Авstract - In this paper, I explore images of evil and (in)humanity in the works of Primo Levi and Charlotte Delbo - verbal images that they encountered within Auschwitz and those that they created afterwards to try to bear witness to what happened there. Verbal images played a crucial role for Levi and Delbo in their efforts both to maintain a sense of their own humanity during their time in the concentration camp and to depict the extent to which inmates' humanity was diminished and degraded by the Nazis. Thus, verbal images helped them both to maintain a sense of their own humanity and to depict the effort to destroy it. This dual role of verbal images found in their testimonies suggests that there is an intimate relationship between evil, images, and (in)humanity during and after the Holocaust - one that we would do well to consider.
\end{abstract}

I use the term 'verbal images' here to refer to words that paint a picture, evoke a scene, or describe something we visualise. Verbal images are words that create 'visual' images in our minds and/or bring into view images already there. They draw our thinking and emotions towards a focal image. On the one hand, verbal images can deceive and seduce us towards evil - for example, propaganda can deploy destructive stereotypes and evoke images that mobilise hatred and justify harm and violence. Harmful images tend to shut down reflection and activate strong negative emotions, putting the viewer or visualiser in a passive or obedient mode. Harmful images often confirm what is already known, and justify the familiar, suggesting that there is no need for further reflection. But verbal images can also help us to see that which was previously invisible to us, can enable us to catch a glimpse of what we are unable to see fully or clearly. They can challenge us to think, reflect, reconsider. They can remind us that we share our common humanity with those who seem quite different from us, enabling us to re-view others as friends and neighbours to whom we owe our attention and care and engagement, rather than strangers we can overlook or enemies we can harm or kill. In other words, whether a verbal image mobilises hate or care tends to depend on the kinds of narratives and emotions it activates within us, on the kinds of beliefs it reaffirms or challenges, on the interpretive and reflective activity it generates or shuts down.

I begin with two images of evil proposed by Primo Levi, move to an exploration of 'seeing' in the work of Charlotte Delbo, and then close with a discussion of the crucial role of literary works for Levi and Delbo in Auschwitz. My working assumption is that if those in the very depths of suffering found a reorienting or sustaining power in verbal images during that suffering, even if only for a moment, then we cannot discount the reorienting possibilities of verbal images in the aftermath of catastrophe. Thus, while Theodor Adorno famously declared that 'to write poetry after Auschwitz is barbaric' 
(Adorno I98I: 34), it might actually be the case that to discount the power of poetry and its verbal images might itself be 'barbaric', by overlooking the sustenance it can give to those enduring great suffering. ${ }^{1}$ Further, the fact that survivors themselves use verbal images in their efforts to depict the horrors of the Holocaust is an important element to consider when debating the appropriateness and even possibility of representing the Holocaust. ${ }^{2}$ Verbal images about the Holocaust do not claim to give the whole picture'; rather, they offer a glimpse into the horrors and sufferings of what individuals endured under the Nazi regimes. Paying attention to these images is one way we can try to 'hear' or 'see' what they are attempting to say and show to us in their testimonies.

\section{Levi's images of evil}

In his testimony, If This is a Man (Se questo è un uomo), Primo Levi declares: 'if I could encompass all the evil of our time in one image, I would choose this image, which is familiar to me: an emaciated man, head bowed and shoul-

1 Adorno made comments to similar effect in a not-so-famous revision of his earlier statement: 'Perennial suffering has as much right to expression as a tortured man has to scream; hence it may have been wrong to say that after Auschwitz you could no longer write poems'(Adorno I 973: 362).

2 Questions about representation have been central to Holocaust studies for decades. See, for example, Saul Friedlander's edited volume Probing the Limits of Representation: Nazism and the "Final Solution" (1 992), Dominick La Capra's Representing the Holocaust: History, Theory, Trauma (1996), Berel Lang's Holocaust Representation: Art within the Limits of History and Ethics (2000), Jessica Lang's Textual Silence: Unreadability and the Holocaust (2017), Michael Rothberg's Traumatic Realism: The Demands of Holocaust Realism (2000), and James E. Young's Writing and Rewriting the Holocaust: Narrative and the Consequences of Interpretation (I 988). ders bent, on whose face and in whose eyes no trace of thought can be seen'(Levi 20 I 5: 85).3 In this short passage, Levi draws together several key themes of this special issue - evil, images, humanity and inhumanity - in surprising and provocative ways. Levi evokes the visual image of an emaciated camp inmate whom we can see with our imagination; his verbal image connects with the photographic images taken by soldiers liberating the camps that have become a part of the iconography of the Holocaust. Levi proposes that this visual image - the image of the emaciated man - might serve as a kind of conceptual image, a representation, of 'all the evil of our time'. Two curious aspects of this passage bear exploration, in particular: first, the surprising choice of the image of the victim, rather than the perpetrator, as the image of evil; and second, Levi's use of the conditional 'if'.

Levi proposes a particular image of evil: 'an emaciated man, head bowed and shoulders bent, on whose face and in whose eyes no trace of thought can be seen'. Why does Levi choose an image of the victim as the one image to enclose all the evil of our time? Why not choose the image of a Nazi guard? Or Hitler? Or a swastika? While Emmauel Levinas suggests that 'it is ... through evil that suffering is understood' (Levinas I998: 92), Levi seems to be suggesting the opposite, that it is through suffering that evil is understood, that it is the image of the emaciated concentration camp inmate, nearing death, that might encompass all the evil of that time. One reason for Levi's choice might be that

3 The translation of the title of Levi's book is itself a topic relevant to a discussion of verbal images. While the title was translated as If This is a Man in the English translation of the book sold in the UK, the American publisher changed the title to Survival in Auschwitz, a change that suggests an emphasis on triumph over suffering, rather than the uncertainty and provocation of the conditional 'if' of the original title that I discuss later in this paper. 
the image of the emaciated man shows the end result of the perverse logic of the Lager. By considering how this emaciated man was reduced to such a state, we have to consider the processes by which the Nazis stripped the inmate of the markers of his identity and personhood: from the earliest losses of job, social status, citizenship, rights, home, neighbourhood, and possessions to the later losses of family members, clothes, hair, and name, to the final losses of the ability to think, imagine, hope, and feel.

With this image, Levi points to what he calls the 'demolition of a man' (Levi 2015:22), the deconstruction of the person, the silencing of his humanity, as the essence of the evil inflicted by the Nazis on the Jews of Europe. Sam Magavern suggests, "his core idea is not, as the back jacket of the American edition says, "the indestructible human spirit"; it is precisely the opposite: that the human spirit can be quickly demolished when absolute power is combined with a dehumanising view of others. This is why Levi's "one image" for the evil of our time is not the image of a Nazi, but rather a Nazi victim' (Magavern 2009: 49). But just what does Levi mean when he speaks of the 'demolition of a man' and what constitutes the 'dehumanising view of others' and the demolishing of the human spirit to which Magavern refers? Let us look at one other image before addressing these questions.

Levi suggests another visual image that might represent all the evil of that time, and this image, in contrast to the first, is an image of a Nazi, and particularly that Nazi's 'dehumanising view'. Levi describes being brought before Dr Pannwitz, a chemist in Buna, who asks Levi a series of questions to find out if he knows anything that might be of use in the Nazis' effort to produce synthetic rubber. It is an absurd moment for Levi: a chemical examination in Auschwitz. He wonders 'Are they aware of the grotesque and absurd test that is asked of us, of us who are no longer alive, of us who are already half mad in the grim expectation of nothing?'
(Levi 201 5:98). And yet, as he begins to answer the questions posed to him, he finds that his memory awakens and his knowledge of organic chemistry returns, and with it returns part of his identity, of who he was before being reduced to a number. He writes, 'this sense of lucid elation, this excitement which I feel warm in my veins, I recognise it, it is the fever of exams, my fever of my exams, the spontaneous mobilisation of all my logical faculties and all my knowledge that my classmates so envied' (Levi 20I 5: IOI). Levi depicts the awakening of his emaciated, 'no-longer-alive' self.

Levi recounts the exchange just before this scene of reawakening, in which Dr Pannwitz sees Levi not as a resurrected human, but as a creature of a lesser species. It is his mode of seeing that is crucial: the gaze of Dr Pannwitz on Levi, the gaze that sees not a human being standing in front of him, emaciated and clothed in rags, but a thing to be utilised. Levi describes the scene:

When he finished writing, he raised his eyes and looked at me.

Since that day I have thought about Doktor Pannwitz many times and in many ways. I have asked myself about his inner workings as a man ...

Because that look did not pass between two men; and if I knew how to explain fully the nature of that look, exchanged as if through the glass wall of an aquarium between two beings who inhabit different worlds, I would also be able to explain the essence of the great insanity of the Third Reich ....

The brain that governed those blue eyes and those manicured hands said, 'This something in front of me belongs to a species that it is obviously right to suppress. In this particular case, one has first to make sure that it does not contain some useful element. (Levi 201 5 : IOO-I) 
As in the previous passage, Levi again suggests an image that might represent the evil of that time: Dr Pannwitz's look at him in that moment, his mode of seeing, becomes an image linked to explaining the 'great insanity of the Third Reich'. Pannwitz reveals a perverse and wilful overlooking of Levi's humanity, seeing instead 'this something'. Pannwitz fails to see the emaciated human being in front of him answering his difficult chemistry questions, and instead sees a thing devoid of humanity, whose remaining knowledge is to be extracted before extermination. The image of evil here is a mode of seeing, or, rather, non-seeing, of one human being looking at another, without any recognition of that person's humanity.

Levi identifies for us, then, two images of evil, which when brought together map out a spectrum of images and of seeing: from Pannwitz's humanity-unseeing gaze to the unseeing eyes of an emaciated man, one of those whom Levi calls the 'non-men who march and labor in silence, the divine spark dead within them, already too empty to truly suffer. One hesitates to call them living; one hesitates to call their death death' (Levi 2015: 85). The perpetrator who does not see the humanity of the victim inflicts violence on him until the victim can no longer see or think or imagine, such that he loses the appearance of a human to those around him. The emaciated man is the end product of Pannwitz's inhumane mode of seeing. It is perhaps by bringing these two images together that we begin to understand more about the particular evil inflicted upon the Jewish victims of the Nazi concentration camps.

These two images put us squarely in the middle of contemporary debates about dehumanisation. Levi's image of the Muselmann seems to be the exact picture of the dehumanised subject; Pannwitz's gaze provides a perfect example of what Magavern calls the 'dehumanizing view of others'. Is Levi suggesting that Pannwitz actually cannot see Levi's humanity, that the Muselmann is truly no longer human, and that humans in fact have the power to transform other humans into non-humans? Is Levi arguing that the key to understanding Nazi violence is dehumanisation? As Johannes Lang has convincingly argued, 'an emphasis on dehumanization in explanations of genocide obscures the nature of human destructiveness by transforming conceptually the relationship between perpetrator and victim - a transformation that distorts the psychological quality of the violence' (Lang 2010: 225). He argues that a recognition of the humanity of the victim is actually integral to some forms and acts of excessive violence, that the humanity of their victims is often both fully visible and meaningfully important to perpetrators in the very commission of their crimes.

In addition to empirical evidence to the contrary, the emphasis on dehumanisation as the key lens through which to understand the violence of the Holocaust and other genocides also raises ethical and ontological questions. To claim that the human can be transformed into the non-human suggests that humanity is a malleable category, rather than an ontological given. Who has the authority to say that a human body is no longer a human? By what power would such a pronouncement have legitimacy? The Nazis redescribed Jews as vermin, not-human, implicitly claiming that they had the power to draw the definitional boundaries of who is inside and outside humanity. As we have seen throughout history, definitions of the human tend to be made when one group seeks to justify their murder or oppression of another group. To state that humans can be transformed into non-humans suggests that humans have the power to expel someone from the realm of humanity, the power to 'withdraw' their humanness. Might it be ethically required to affirm the humanity of the Muselmann, in resistance to the Nazis' 'fantastic hegemonic' claim to have the authority and ability to expel groups of people 
from the realm of the human at will? 4

But why, then, does Levi describe the Muselmann as a non-man, and the experience in the camps as the 'demolition of a man'? Why does he focus on this figure of extreme depletion, the Muselmann, as the prime candidate for the image of evil of that time? One reason might be because it is too easy to underestimate the extent of the Nazi assault on the camp inmate. In order to acknowledge the depth of the Nazi effort against the Jews, the demolition of the person that the concentration camp was organised to effect, we must register the ways in which human beings were reduced to bare existence, in which their thinking and feeling and responsiveness was silenced. But might another reason be that he does, in fact, think the Muselmann was a human being transformed into a non-human? A closer examination of the rhetorical structures within which Levi proposes his two images of evil is needed in order to think more about this question.

\section{The space of 'if'}

What is particularly interesting to note about both images is that Levi introduces them with the conditional 'if': 'if I could encompass all the evil of our time in one image ...'; 'if I knew how to explain fully the nature of that look ...'. What sort of rhetorical space is created by the use of 'if' and why does Levi set up his images of evil in this way?

Levi inserts uncertainty into his first proposal of an image of evil by beginning with

4 Here I draw on the language of womanist theologian Emilie Townes in her book Womanist Ethics and the Production of Evil, in which she speaks of the 'fantastic hegemonic imagination' to describe the 'deep cultural codings' in the United States that 'traffic in [Black] people's lives' and 'hold systematic, structural evil in place' to 'control the world in its own [White] image' (2 I). the conditional 'if': 'if I could encompass all the evil of our time in one image ...'. In fact, even the location of the uncertainty raised here is itself uncertain. The 'if' could relate to Levi's confidence in his capacities to come up with an image that could encompass evil: he might be suggesting that this sort of image of evil is possible, but that he himself cannot make it. Read this way, the passage might be saying, 'If I could encompass all the evil of our time in one image, I would choose this image ... but I am not able to do so, even though others might be able to do so'. In the context of writing about his experiences in Auschwitz, this doubting of his own capacities for image-making might not seem surprising, given the horrors of the concentration camp and the ways in which bodily and mental functions were harmed and debilitated. That someone who has endured such a situation might wonder about his capacities of imagination is not surprising. Self-doubt itself may be a legacy of the 'all the evil of our time' - a wounding that continues long after the physical wounds have healed.

But Levi writes this in the aftermath of the concentration camp, from a situation in which his thinking and imaginative capacities have returned at least in part. Despite the possibility of self-doubt about his capacity to come up with an image of 'all the evil of our time', the Levi who has returned home to Turin and is feverishly writing down his experiences in the months after the end of the Holocaust, does, in fact, offer us an image. This might suggest that the conditional 'if' is used not because Levi doubts his own image-making capacities, but rather because he doubts the very possibility of the task itself, the possibility of enclosing evil in an image. It might read 'If I could encompass all the evil of our time in one image, I would choose this image, but evil cannot be so enclosed'. Here Levi would be joining the chorus of those who see in evil a kind of excess, a negative transcendence, an elusive quality, a slipperiness that 
makes it difficult to pin down, identify, define, or enclose, suggesting that evil is not the kind of thing that can be enclosed by anything.

Or, the 'if' could relate to the capacity of merely one image to carry this weight. As such, it could be read as saying, "If I could encompass all the evil of our time in one image, I would choose this image, but one image is hardly enough to accomplish such a task - we need more than one image if we are to enclose evil'. This points to the importance of images in communicating the realities of evil, but also suggests that we need multiple images to do so.

Or, the 'if' could characterise not the inadequacies of Levi's own image-making capacities, or evil's resistance to being encompassed, or the limits of what merely one image can represent, but rather it could refer specifically to the particular nature or quantity of the evil of our time - the evil of the Shoah, in particular. As such, it might be read as saying "If I could encompass all the evil of our time in one image, I would choose this image, but I know that the horror and quantity of evil of the Shoah exceeds even the image I am about to present to you'. Here we could read Levi as speaking within the double bind that Sarah Kofman describes in Smothered Words (1998) - the simultaneous necessity and impossibility of speaking about the Holocaust. While in the past evil may have been such that it could be contained within one image, the evil of the Holocaust cannot be so contained, enclosed, or expressed. Levi here might be suggesting something similar to what Levinas argues in 'Useless suffering', when he suggests that we have witnessed 'the destruction of all balance between Western thought's explicit and implicit theodicy and the forms that suffering and its evil [have taken] on in the very unfolding of [the twentieth] century' (Levinas r 998: 97). While theodicy or one image may have been sufficient to grapple with past evils, neither is capable of doing so with the evils of the Shoah.

These various ways that Levi's conditional statement can be read suggest the productive uncertainty that Levi brings to his images of evil - uncertainty because the word 'if' suggests a hypothetical, something that cannot be ascertained to be the case or not be the case, and expansive because it invites us to consider it from multiple viewpoints, to consider the possible ways we might read or locate this uncertainty.

Returning to the question of what Levi is saying about dehumanisation with this recognition of the uncertainty and indeterminacy with which he frames his images of evil, we can see that Levi is not claiming that the Muselmann has been 'dehumanised', but neither is he claiming that he has not been dehumanised - Levi is raising the question and challenging us to consider it. In fact, it is precisely the inability to say this is or is not a human being - the terrible indeterminacy of the Muselmann - that is so troubling, that must be considered. As Giorgio Agamben notes, for Levi, 'in Auschwitz ethics begins precisely at the point where the Muselmann, the "complete witness", makes it forever impossible to distinguish between man and non-man' (Agamben 2002: 47). It is precisely this indeterminacy that Levi challenges us to consider in his title If This is a Man and in the poem that serves as the epigraph to his testimony. Giorgio Agamben, however, at times forgets this prohibition against determinacy, as when he describes Auschwitz as 'the site of an experiment that remains unthought today, an experiment beyond life and death in which the Jew is transformed into a Muselmann and the human being into a non-human' (ibid. 52 ). Levi is suggesting that what must be thought, considered, meditated on, is not that the human has become the non-human, but that we cannot resolve the indeterminacy, that we must remain in this uncomfortable space of considering if.

The word 'if' invites the listener to consider along with the speaker - it is, thus, a communal word. It creates a hypothetical situation to which the listener or reader is invited (or commanded) 
to pay attention. By using the conditional 'if' to begin his proposal about the possibility of enclosing all of the evil of our time in one image, Levi rhetorically invites us into this imaginative space of possibility and uncertainty, raising the possibility of what enclosing evil in one image might look like or what an image for explaining the 'insanity' of the Third Reich might be, while also pointing to the impossibility of any image standing in for or leading to a full explanation of evil. When Levi writes, 'if I knew how to explain fully the nature of that look ... I would also be able to explain the essence of the great insanity of the Third Reich', he is not suggesting that a dehumanising look - a look that sees the human as not a human - explains all Nazi violence, but he is suggesting that the unattainable ability to explain one would enable one to explain the other.

The space created by the introduction of the word 'if' is a paradoxical space - paradoxical because in proposing one image to encompass the evil of that time, Levi is also opening up space for thinking about its impossibility, for thinking about what one image of evil can or cannot accomplish. This space asks us to consider what it might mean to enclose the Nazi evil in one image, to think about what the image of the emaciated man with no trace of thought in his eyes might say about 'all the evil of our time', to consider if this is a human being. In other words, what Levi's short conditional proposal creates is a communal space of painful indeterminacy in which we must ask questions together - it is the very space in which his whole testimony is written.

For 'if' is also the first word of Levi's title If This is a Man - the word that invites us into his testimony in the first place. Levi asks us to read his whole testimony within space of if - to consider if this is a man. Leland de la Durantaye suggests that 'the rendering conditional that Levi employs poses the simple and terrifying question of how men did what they did; how, if this - the concentration camp prisoner - is a man, he could be treated by other men in such a fashion. This question concerning the project of dehumanisation that lies at the heart of the Nazi concentration camps, and the ensuing doubt as to the solidity of our conceptions of humanity and its nature, is, from the book's first words, that to which Levi's work testifies' (de la Durantaye 2009: 249). In slight contrast to de la Durantaye, I might suggest that the conditional 'if' of the title asks not so much 'how men did what they did', but rather how we are to understand the depths of the assault made on the prisoner. How far does the infliction of destruction go? How far can one demolish a person? Can evil destroy an individual's humanity, leaving only a suffering body? Levi suggests that it is not a question with a clear answer, but one we need to face and spend time considering - not so as to come up with a definitive answer, but rather to begin to understand the implications of the horror that makes these askable questions.

Further, Levi's testimony opens with a poem - or perhaps we might call it a prayer, echoing as it does the daily Jewish prayer of the Shema, or even a curse - that dramatically thrusts the reader into the space of 'if', reiterating the 'if" of Levi's title and raising these very questions about what constitutes one's humanity. The poem intensifies the tone and urgency of the invitation to consider if the emaciated man with no trace of thought in his face is still a man. In fact, the poem does not so much invite as command us into the 'space of if'; Levi tells us to 'Consider if this is a man / Who toils in the mud .... Consider if this is a woman, / With no hair and no name' (Levi 2015: 7). As Nancy Harrowitz notes, 'The role that Levi as survivor and as writer embraces is to command rather than commend remembrance, through this evocative rewriting of the most central prayer in the Jewish tradition' (Harrowitz 2016: 26). The ifs in this poem - along with the if of the book's title and the ifs of the two images of evil that he 
proposes - constitute an invitation/challenge/ command to consider those who suffered in the camps and the evil that brought them to this emaciated state, to remember what happened, and to teach it to those who can continue the task of considering and remembering. He ends the poem with a kind of curse for the failure to do so: 'Or may your house fall down, / May illness make you helpless, / And may your children turn their eyes from you' (Levi 2015:7).

The tension between the image that encompasses evil and the 'if' that opens up space to think about it, between the evils that reduce humans down to seemingly empty vessels and the imagination that allows them to expand their current situation - this is the painful and productive tension within which Levi asks us to dwell as we read his work. Levi is calling us into a space of ambiguity and uncertainty in which we are called to question the very task of image-making, the nature of evil, the particular nature of the evil of the Holocaust, a space in which we are called to responsibility - the responsibility to think, question, consider, but also a space in which we must forego the pleasures and comforts of certainty and closure. We must contend with the tension between our desire to enclose or contain evil in images and the counter movement of images to open up and multiply.

But we might consider Levi's 'if' as an invitation to a different mode of seeing - one that asks questions, invites others to consider if, and is aware of multiple possibilities. Levi has seen and remembers and bears witness to the emaciated ones in the camps. Levi has looked into the eyes and face of the emaciated man, searching for a trace of thought. In contrast to Pannwitz's mode of seeing him, Levi sees the emaciated man against the backdrop of his humanity, of who he used to be and to whom he now seems so dissimilar.

Levi's insertion of the 'if' reminds us of the uncertainty that must accompany our foray into questions about evil and suggests several things to think about as we consider the connections between evil, (in)humanity, and images. First, images of evil cannot be certain or definitive or singular. Second, in thinking about images of evil we contend with the tension between our desire to contain or encompass or understand evil and the impossibility of doing so, along with the need to be able to say or see at least something about it. Third, in any consideration of evil, we need to keep in view the suffering of the victim, particularly since evildoers use images to mask the violence of their aims and actions with glorious-looking symbols. Finally, considering together possible images of evil may be one way to build a community of resistance - or at least a communal activity of considering what evil is and what its consequences are. Considering if, together, is a morally required response to evil.

\section{Delbo's images and the ethics of seeing}

I would like to turn now to another survivor of the camps, Charlotte Delbo, who also meditates on images of evil and pays particular attention to the activity of seeing. As should be clear by now, 'seeing' is itself a kind of verbal image, that is, we can imagine a mode of ethical engagement as a kind of seeing involving our attention, our understanding, and our openness to that which is before us and yet not visible with our eyes. We can visualise or imagine that activity in the image of someone seeing something with their eyes. As Claudia Welz notes: 'Taken in its broadest sense, "visibility" synesthetically unites the experiences of all our senses. It might even include intuition and intellectual insight. As a result "seeing" can in some senses be equivalent to "understanding"' (Welz 2or 6: 2).

In Auschwitz and After (1995), Delbo notes that one learns, after enduring the camps, that the ability to think and imagine is a 'luxury' that depends on the sustenance of a certain level of physical and emotional well-being. She writes: 
You may say that one can take away everything from a human being except the faculty of thinking and imagining. You have no idea. One can turn a human being into a skeleton gurgling with diarrhea, without time or energy to think. Imagination is the first luxury of a body receiving sufficient nourishment, enjoying a margin of free time, possessing the rudiments from which dreams are fashioned.

People did not dream in Auschwitz, they were in a state of delirium. (Delbo I 995: I68)

Delbo's image of a 'skeleton gurgling with diarrhea' connects with Levi's image of the emaciated man - both are bodies rendered unable to think or imagine by the horrors of concentration camp life. Both Levi and Delbo compose these verbal images in the effort to get the reader to imagine and 'see', to begin to understand what happened in Auschwitz.

'Try to look, try to see ...'- with these words, Delbo calls to, challenges, and commands somehow, like Levi, she manages to do all three at the same time - her readers to try to see and to try to understand what happened in the Nazi concentration camps. In Delbo's call and in our response to that call, we readers encounter our reluctance to look and our strategies to avoid seeing what makes us uncomfortable, what does not fit with our preconceptions, what disrupts our categories of understanding. What seems to be the most natural and unencumbered mode of engagement - seeing - is revealed to be much more complicated and fraught than we realise. Our seeing is shaped by our desires and by our fears, by our expectations and by our evasions.

A member of the French Resistance who was sent to Auschwitz-Birkenau and then Ravensbrück, Delbo depicts the sufferings she and her comrades, as she calls them, endured at the hands of the Nazis through a mix of genres and voices in Auschwitz and After. Lyrical poetry mixes with short vignettes of camp life; direct address is juxtaposed with third-person narratives. The result is a deeply powerful and unsettling testimony of extreme suffering. Lawrence Langer describes it as a 'unique blend of poetry and prose, resulting in a lyrical rendering of atrocity that is alarmingly beautiful, an aesthetics of agitation' (Langer I 995: Xvi). It is a work replete with images.

Particularly in the first volume, None of $U_{s}$ Will Return, Delbo describes scenes of looking and seeing and interjects these with calls to 'try to look, try to see' to her reader. But she also includes scenes in which she and others are desperately trying not to look, or cannot see, as well as admonitions to her readers not to look. By reflecting on the scenes of seeing and not seeing that Delbo depicts, alongside her challenges to us to look or not look, we begin to understand more of the task she set for herself, noted by her translator: 'Je veux donner à voir!' (Lamont I 995: vii).

Delbo begins her testimony with a description of a train station, creating a visual image within our minds, much like the stage directions for a play: 'People arrive. They look through the crowd of those who are waiting, those who await them. They kiss them and say the trip exhausted them' (Delbo r 995: 3). For most readers, this is familiar terrain. Even those who have never travelled by train can conjure up images of the waiting crowd on the station platform, the expectant faces, the excited anticipation. The visual image appears easily before our eyes.

But then, after the space of a line break in the text, Delbo moves us to unfamiliar terrain: 'But there is a station where those who arrive are those who are leaving / a station where those who arrive have never arrived, where those who have left never came back' (Delbo r 995: 3). The clean and clear distinction between those who are arriving and those who are leaving suddenly no longer works. Even the punctuation becomes confused: the clear sentences of the opening become fragments; prose becomes poetry. In this station, our categories for understanding 
arrival and departure collapse, become confused, and fail to help us to find our way. This is not the station we first visualised. This abrupt shift from familiar to unfamiliar territory unsettles the reader, making her have to scramble to try to make sense of this new station. The passengers at this station, Delbo tells us, 'expect the worst - not the unthinkable' (ibid. 4). As readers of Delbo's text, we realise that we, too, have moved from the expected and familiar to the unthinkable. We cannot make sense of this new place where arrivals and departures are confused: we are confronted with something we cannot think. Delbo uses verbal images to help us to see what we cannot think.

We first encounter this seeing what cannot be thought, what had not been imagined, among members of the Jewish transport with which the book opens. Delbo tells us that the old people think to themselves that 'nothing ever looked like what they see here', and that their children, who send them postcards from foreign lands 'will never believe it' (Delbo r995: 6). Even the intellectuals, those who are trained and skilled in thinking, many of whom 'made use of their imagination to write books', even for them, 'nothing they imagined ever came close to what they see now' (ibid. 6). They are seeing what they could not imagine, and Delbo is trying to get us to imagine what we cannot see, trying to draw us into their confusion through the disorienting opening of her testimony. But this can only take us so far, and Delbo soon abandons a thirdperson, dramaturgical narrative for poetry and prose that addresses us more directly and makes explicit the impossibility of our truly being able to see.

Delbo probes the activity of seeing and its connection to an ethical response. In a short piece recalling Levinas's claim that the face of the other utters the command not to kill, one of the women cannot fathom that the Nazis have killed her beautiful little sister. She says 'they mustn't have looked at her. / If they had, they would never have killed her. / They couldn't have' (Delbo I995: 30). She believes in the power of seeing, believes that an act of looking, of really seeing her sister, would have prevented the Nazis from murdering. It would be impossible to look at her sister and still send her to the gas chambers. And yet, as we know from Levi's image of Dr Pannwitz's gaze, the Nazis' insane way of looking or seeing is unlike any usual mode of seeing.

Delbo intensifies her focus on the act of seeing as None of Us Will Return continues. Narrating her own efforts to avoid looking, the pain involved in seeing, and violence that in one instance severs one's ability to respond to what one sees and in the other instance makes one unable not to see what one desperately tries not to see, Delbo then turns to her readers and challenges them to 'try to look. Just try to see'. This command is repeated three times, on three pages in succession. In the first instance, Delbo describes a corpse that has 'the left eye devoured by a rat. The other open with its fringe of lashes' (Delbo I995: 84). 'Try to look. Just try and see', she challenges us. Next she describes a man, exhausted and unable to keep up, attacked by a dog who bites into the man's backside. The man keeps walking, blood seeping from his backside, 'with the dog's fangs in his flesh' (ibid. 85). Again, she challenges us to 'try to look. Just try to see' (ibid.). In the third scene, Delbo describes a Jewish woman being dragged to block 25, with her shirt wound around her neck and her trousers around her ankles, howling in resistance. Again Delbo challenges us 'try to look. Just try to see'. The repeated challenge follows a break in the narrative - the scene is described, the visual line space offers a pause, and Delbo turns to us with her challenge. These are scenes of excruciating physical pain, humiliation, and intense suffering. We see them too well, owing to the sparse precision of her prose. But we do not want to see them. It is painful to see them. And yet, Delbo calls us to look and to see. 
But as None of Us Will Return continues, Delbo's challenges and commands begin to take a different turn, as if weary or fearful of what she has asked us to see. A few pages later, she writes 'do not look. Do not look at this dummy being dragged on the ground. Do not look at yourself' (Delbo r 995: 89). She seems here to be speaking to herself, telling herself not to look, realising the dangers that seeing can bring. She tells herself, 'better not think, not think at all' (ibid. 90). The triple call to look and try to see is rewritten in the section called 'The Orchestra'. Now we are repeatedly told not to look:

Do not look at the fingers of the cello player, nor at her eyes when she performs, you could not stand it.

Do not observe the movements of the conductor....

Do not look, do not listen ... (Delbo I 995: Iо6)

Do not look at the orchestra playing

'The Merry Widow.'

Do not listen ....

Do not look at the women musicians who play while naked men reduced to skeletons exit driven by blows that make them reel ....

Do not look at the violinist ....

Do not look, do not listen. (Delbo i 995: I07)

Looking is too dangerous, too painful. An exhaustion of moral exhortation has set in. Having dismantled our preconceptions about what we think we know and then challenged us to look and see the horrors of the Holocaust, Delbo now warns us of the dangers, of the damage it will do. But it is too late. Delbo has already made us see, at least in part; she has enabled us to look, to catch a glimpse of the horrors of the Holocaust, and that glimpse has enmeshed us in a duty to respond and remember. She both entreats and warns against the effort to 'see' what happened during the Holocaust. In this shifting admonition, she depicts the moral obligations and costs of looking, of seeing. Seeing is not voyeurism here; it enmeshes one in a responsibility to respond, review, and remember. One becomes a witness with responsibilities to bear testimony to what one has 'seen' through reading Delbo's account.

Delbo writes out of an intense desire to 'make us see', to give us a glimpse of what she experienced and witnessed in Auschwitz, and to bear witness to the lives and sufferings of her 'comrades', to whom she tells us she owes her survival. She writes in such a way as to reconfigure her readers, so that they will be able to 'see'. In order for them to understand, they need to see clearly, or at least glimpse as clearly as possible at this distance in time, space, and circumstance. Seeing, for Delbo, involves the objects, people, and situations we see with our eyes as well as what we visualise internally from what we see, read, and hear. It is both optical and imaginative. Both Delbo's command to 'try to see' and Levi's command to 'consider if' draw us into an ethical space of attention, thought, and response to the evil inflicted by the Nazis and the suffering endured by their victims, and both use images of (in)humanity to draw us into that ethical space.

\section{Literary images of humanity}

While Levi and Delbo focus our attention on images of evil and extreme suffering during the Holocaust in their testimonies, both also suggest that verbal images may serve a crucial role in resisting the efforts to destroy a human being. Each recounts moments in which poems and literary fragments were more important to them even than food. Delbo trades a ration of bread for a copy of Molière's Le Misanthrope, despite her physical hunger and the dangers of missing even one ration of food, and memorises it: 
'I learned Le Misanthrope by heart, a fragment each evening, which I'd repeat to myself at roll call the following day .... And until departure, I kept the play within my throat' (Delbo I995: I88). She speaks of the effort to remember poems and the importance they held for her:

I had succeeded, at the price of infinite efforts, in recalling fifty-seven poems. I was so afraid they might escape my mind that I recited them to myself every day, all of them, one after the other, during roll call. It had been so difficult to reconstruct them! Sometimes it took days for a single line, a word, which simply would not come back. (Delbo i 995 : I88)

These literary works serve as a kind of nourishment for her struggling humanity, as vital as food to her survival - survival beyond sheer physical existence. Memorisation and internal recitation become practices in which she sustains a reality other than the one she is enduring.

Levi, too, describes the difficult and urgent effort to recall lines of poetry and the crucial role of literary images, even in the camps, for helping to sustain something within him beyond physical survival. In the section 'The Canto of Ulysses', he recounts the experience of trying to remember, recite, translate, and explain a canto of Dante's Inferno to one of his fellow inmates. In a world in which the energy needed to survive drains many of their very capacity to think, it might seem strange to read of the urgency with which Levi tries to remember Dante's words. And yet, this urgency is precisely why it is so important for us to pay attention to this scene. Levi writes:

Here, listen, Pikolo, open your ears and your mind, you have to understand, for my sake:

Consider well the seed that gave you birth: you were not made to live your lives as brutes but to be followers of worth and knowledge.
As if, I, too, were hearing it for the first time: like the blast of a trumpet, like the voice of God. For a moment I forget who I am and where I am.

Pikolo begs me to repeat it. How kind Pikolo is, he is aware that it is doing me good. Or perhaps it is something more: perhaps, despite the feeble translation and the pedestrian, rushed commentary, he has received the message, he has understood that it has to do with him, that it has to do with all men who toil, and with us in particular; and that it has to do with us two, who dare to talk about these things with the soup poles on our shoulders. (Levi 2015: 107-8)

The urgency with which Levi tries to remember and tries to communicate what he remembers is underscored when he says, further down, 'I would give today's soup to be able to connect "the highest I had ever seen" to the last lines' (Levi 2015: I09). In a world in which one day's ration can mean the difference between life and death, Levi would choose the missing words of poetry over his ration of soup. Why? Because the process of remembering this image of Ulysses in hell - in a world with parallels to Levi's own - reminds him of his humanity, of a vision of humanity that resists the efforts at dehumanisation that surround him. And the effort to communicate this poetry to his partner Pikolo seems to him 'vitally necessary and urgent' (ibid. ro9).

This is not about the simple comforts of literature - the process of recovering the lines is painful: at one point Dante's words remind him unbearably of the mountains of his homeland - but rather about its intimate connection with Levi's awareness of his own humanity. It speaks to a need even stronger, at some moments, than his need for food. It also underscores the communal nature of verbal images - it is because he is recounting it to Jean, the Pikolo, because there is someone there to hear, perhaps in need of 
hearing, that the verbal image of men made not for brutish ignorance, but knowledge and excellence, takes on such importance. Vicki Mahaffey notes that 'the Italian title of the book, Se questo è un uomo, "if this be a man," abuts against the insistence of Dante through the voice of Ulysses recited by Levi that "you were made men". She suggests that in this passage we see 'the power of literature: it is a fire, a voice, that can sound through hell and address itself even to the damned ... it is a thought-charged moment with a flickering power to restore their ability to think and feel in a meaningless, highly regulated social environment' (Mahaffey 2007: 49).

In thinking about the possibilities of images both during and after catastrophes, one final passage from Levi serves to underscore the importance of images for communicating not only the effort to destroy one's humanity but also the possibility of maintaining it in the face of that effort. Levi describes the actions of an Italian civilian worker who smuggled food to him every day for six months in the factory. While this food enabled Levi to survive physically, it is not the food that Levi remembers most. He writes,

I believe that I owe it to Lorenzo if I am alive today; and not so much for his material aid as for his having constantly reminded me by his presence, by his natural and plain manner of being good, that a just world still existed outside ours, something and someone still pure and whole, not corrupt, not savage, unconnected to hatred and fear: something difficult to define, a remote possibility of good, but for which it was worth surviving .... Thanks to Lorenzo, I managed not to forget that I myself was a man. (Levi 20I 5: I I5-I6)

Here Levi uses words to evoke for us the image of Lorenzo, whose actions during the Holocaust enabled Levi to keep present to mind the vision of a world outside of the camps, of a sense of humanity other than that exhibited by the Nazis. Lorenzo's presence functions as an image of a just world and reminds Levi of his own humanity. Here humanity is presented as something that can be forgotten, rather than destroyed; the Muselmann might be reconceived as the one who no longer has the energy left to remember his own humanity in the face of a world that declares him not-human and treats him likewise.

In writing this passage, Levi creates for us an image of humanity that stands alongside and in contrast to both the emaciated man and the gaze of Dr Pannwitz. All of these images stand within the conditional space of the 'if' of Levi's title - If This is a Man - in which we are challenged to consider, question, and meditate; to remember and repeat what happened during the Holocaust, being wary of answers that are too confident, images that are too easy, and comforts that may be too costly.

For both Levi and Delbo, verbal images are of crucial importance after the Holocaust - they both write, after all, after the catastrophe, creating their images in its aftermath, asking and commanding us to look at these images, to consider and meditate on them, to remember and respond to them, suggesting that these images are of utmost importance, even while they may not lead to the specific answers we seek or the explanations we desire. While Levi and Delbo assert that readers' ability to understand what happened in Auschwitz is severely limited, they consider both the effort to communicate it and the effort to understand it as urgently important - and the depiction of images as crucial to that effort. They also recount encounters with verbal images that enabled them to hold onto and remember a sense of their own humanity, even if only fleetingly, amidst the extreme suffering. In both situations, they are urgent in their belief in the power of verbal images and the need to pay attention to them and, thus, challenge us to do so. 


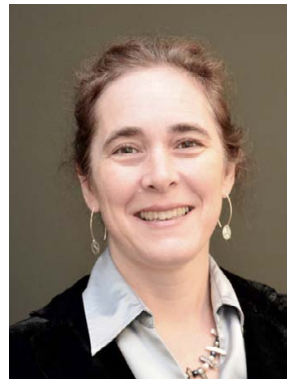

Jennifer L. Geddes, Associate Professor of Religious Studies at the University of Virginia, is the author of Kafka's Ethics of Interpretation: Between Tyranny and Despair (Northwestern University Press, 2016), editor of Evil After Postmodernism: Histories, Narratives, Ethics (Routledge, 2001), and coeditor of The Double Binds of Ethics after the Holocaust: Salvaging the Fragments (Palgrave Macmillan, 2005).

\section{References}

Adorno, Theodor W., I 973. Negative Dialectics, trans. E. B. Ashton (London, Continuum)

- 98 r. Prisms, trans. Shierry Weber Nicholsen and Samuel Weber (Cambridge, MA, MIT Press)

Agamben, Giorgio, 2002. Remnants of Auschwitz: The Witness and the Archive, trans. Daniel Heller-Roazen (New York, Zone Books)

Delbo, Charlotte, I 995. Auschwitz and After, trans. Rosette C. Lamont (New Haven, CT, Yale University Press)

De la Durantaye, Leland, 2009. Giorgio Agamben: $A$ Critical Introduction (Palo Alto, CA, Stanford University Press)

Friedlander, Saul, (ed.) I992. Probing the Limits of Representation: Nazism and the "Final Solution" (Cambridge, MA, Harvard University Press)

Harrowitz, Nancy, 2o I6. Primo Levi and the Identity of a Survivor (University of Toronto Press)

Kofman, Sarah, I998. Smothered Words, trans. Madeleine Dobie (Evanston, IL, Northwestern University Press)

La Capra, Dominick, 1 996. Representing the Holocaust: History, Theory, Trauma (Ithaca, NY, Cornell University Press)

Lamont, Rosette C., I 995. 'Translator's Preface', Auschwitz and After, Charlotte Delbo, trans. Rosette C. Lamont (New Haven, CT, Yale University Press), pp. vii-viii

Lang, Berel, 200o. Holocaust Representation: Art within the Limits of History and Ethics (Baltimore MD, Johns Hopkins University Press)

Lang, Jessica, 201 7. Textual Silence: Unreadability and the Holocaust (New Brunswick, NJ,

Rutgers University Press)

Lang, Johannes, 20 Iо. 'Questioning dehumanization: intersubjective dimensions of violence in the Nazi concentration and death camps', Holocaust and Genocide Studies, 24(2), pp. 225-46

Langer, Lawrence L., I 995. 'Introduction to the second edition,' Auschwitz and After, Charlotte Delbo, trans. Rosette C. Lamont (New Haven, CT, Yale University Press), pp. ix-xxvii

Levi, Primo, I 993. Se questo è un uomo (Torino, l'Unità/Einaudi)

-201 5. If This is a Man, The Complete Works of Primo Levi, vol. I, trans. Stuart Woolf (New

York, Liveright Publishing), pp. I-205

Levinas, Emmanuel, I 998. 'Useless suffering', Entre Nous: Thinking-of-the-Other, trans. Michael B. Smith and Barbara Harshav (New York, Columbia University Press), pp. 9 I-Io I

Magavern, Sam, 2009. Primo Levi's University: A Writer's Journey (New York, St Martin's Press)

Mahaffey, Vicki, 2007. Modernist Literature: Challenging Fictions? (Malden, MA, WileyBlackwell)

Rothberg, Michael, 200o. Traumatic Realism: The Demands of Holocaust Realism (Minneapolis, University of Minnesota Press)

Townes, Emilie M. 2006. Womanist Ethics and the Cultural Production of Evil (Basingstoke, Palgrave MacMillan)

Welz, Claudia, 20 I6. Humanity in God's Image: An Interdisciplinary Exploration (Oxford University Press)

Young, James E. I 988. Writing and Rewriting the Holocaust: Narrative and the Consequences of Interpretation (Bloomington, Indiana University Press) 